NBER WORKING PAPER SERIES

\title{
EARLY EVIDENCE ON THE IMPACT OF COVID-19 AND THE RECESSION ON OLDER WORKERS
}

\author{
Truc Thi Mai Bui \\ Patrick Button \\ Elyce G. Picciotti \\ Working Paper 27448 \\ http://www.nber.org/papers/w27448 \\ NATIONAL BUREAU OF ECONOMIC RESEARCH \\ 1050 Massachusetts Avenue \\ Cambridge, MA 02138 \\ June 2020
}

This paper was prepared for a special, forthcoming issue of Public Policy \& Aging Report. We thank Brian Kaskie and Kerui Geng for helpful comments. The views expressed herein are those of the authors and do not necessarily reflect the views of the National Bureau of Economic Research.

NBER working papers are circulated for discussion and comment purposes. They have not been peer-reviewed or been subject to the review by the NBER Board of Directors that accompanies official NBER publications.

(C) 2020 by Truc Thi Mai Bui, Patrick Button, and Elyce G. Picciotti. All rights reserved. Short sections of text, not to exceed two paragraphs, may be quoted without explicit permission provided that full credit, including $\odot$ notice, is given to the source. 
Early Evidence on the Impact of COVID-19 and the Recession on Older Workers

Truc Thi Mai Bui, Patrick Button, and Elyce G. Picciotti

NBER Working Paper No. 27448

June 2020

JEL No. I14,J14,J16,J26

\begin{abstract}
We summarize some of the early effects and discuss possible future effects of the COVID-19 pandemic and recession on the employment outcomes of older workers in the United States. We start by discussing what we know about how older workers faired in prior recessions in the United States and how COVID-19 and this recession may differ. We then estimate some early effects of the COVID-19 pandemic and recession on employment and unemployment rates by age group and sex using Current Population Survey data. We calculate employment and unemployment rates multiple ways to account for the complicated employment situation and possible errors in survey enumeration. We find that while previous recessions, in some ways, did not affect employment outcomes for older workers as much, this recession disproportionately affected older workers of ages 65 and older. For example, we find that unemployment rates in April 2020 increased to $15.43 \%$ for those ages 65 and older, compared to $12.99 \%$ for those ages 25-44. We also find that COVID-19 and the recession disproportionately affected women, where women have reached higher unemployment rates than men, which was consistent for all age groups and unemployment rate measures we used.
\end{abstract}

Truc Thi Mai Bui

Department of Economics

Tulane University

6823 St. Charles Avenue

New Orleans, LA 70118

United States

tbui7@tulane.edu

Patrick Button

Department of Economics

Tulane University

6823 St. Charles Avenue

New Orleans, LA 70118

and NBER

pbutton@tulane.edu
Elyce G. Picciotti

Tulane Center for Aging

Tulane University

1430 Tulane Avenue

New Orleans, LA 70112

epicciotti@tulane.edu 


\section{Introduction}

The arrival of the SARS-CoV-2, the virus that causes coronavirus disease 2019 (COVID19), led to pandemic that significantly upended economies and strained health care and social welfare systems worldwide. The United States confirmed its first case on January 21, 2020. As of June 18, there were 24,498 new cases, and a total of 2.24 million confirmed cases, 699,063 recoveries, and 120,302 deaths in the United States (1Point3Acres, 2020).

The COVID-19 pandemic and the policies to curb its spread brought parts of the U.S. economy to a virtual halt in March 2020. Payroll jobs declined by 0.7 million in March 2020 and 20.5 million in April 2020, pushing the seasonally adjusted official unemployment rate (U-3) to a peak of 14.7\% in April 2020 (U.S. Bureau of Labor Statistics, 2020a, 2020b). This rate surpasses the peak rates during the Great Recession (10.6\%, January 2010) and the early 1980s recession (11.4\%, January 1983) (U.S. Bureau of Labor Statistics, 2020c). However, even these high unemployment rates during the COVID-19 pandemic are severely underestimated, as we discussed later, with a more realistic unemployment rate being at least 21.6\% in March 2020 (Montenovo et al., 2020).

There is limited analysis of how the COVID-19 pandemic, and resulting recession, impact older workers. In this report, we summarize the early effects and discuss possible future effects of the COVID-19 pandemic and recession on older workers in the United States. We start by discussing what we know about how older workers faired in prior recessions in the United States and how COVID-19 and this recession may differ. We then estimate some early effects of the COVID-19 pandemic and recession on employment and unemployment rates by age group and sex. We conclude with a brief discussion of important topics for future research as the pandemic develops and hopefully resolves, and as new data sources become available. 


\section{How Did Older Workers Fare in Previous Recessions?}

Knowing how older workers fared in prior recessions may help forecast how they will be affected in this recession. Prior research shows that older workers are differentially affected by recessions. One way they are less impacted is that in prior recessions, the probability of displacement generally declined with age since older workers often benefitted from employment seniority (Johnson \& Butrica, 2012). Older people also faced smaller increases in their unemployment rate, (Johnson \& Butrica, 2012 and Figure 3) although that is partly because older people are more likely to leave the labor force.

In other ways, recessions hit older workers harder. Older workers took longer to find work during and after the Great Recession (Neumark \& Button, 2014), and unemployed workers in their fifties also faced steeper wage losses (Johnson \& Butrica, 2012). Age discrimination in hiring also increases during recessions, contributing to the longer unemployment durations for older workers. Age discrimination is a significant barrier for older workers who often take temporary jobs - called bridge jobs - to delay retirement (Neumark, Burn \& Button, 2019).

Regardless of whether older workers face a more significant negative economic shock, a given shock could affect them more. Coile et al. (2014) find that workers approaching retirement during a recession are disproportionately likely to suffer long-lasting negative consequences, including years of reduced replacement earnings, loss of healthcare coverage, lower utilization of healthcare, and reduced longevity.

Decreases in retirement accounts also affect older people more. Munnell \& Rutledge (2013) and Munnell, Webb \& Golub-Sass (2012) summarize the decreases in retirement security that older people faced during and after the Great Recession, finding, for example that the National Retirement Risk Index (NRRI) rose from 44 in 2007 to 52 in 2010. The NRRI estimates the share 
of working households who are "at risk" for being unable to maintain their preretirement standard of living in retirement (Munnell \& Rutledge, 2013).

Younger people were, of course, less affected as they did not need to access retirement savings and had longer to recover from losses. Older workers had only three options: save more, work longer, or live on less in retirement (Munnell \& Rutledge, 2013). Saving more was difficult given the short time frame and low interest rates. Working longer is a great option but is frustrated by a weak economy and age discrimination that may increase during a recession. Partly for this reason, early retirement increases during and after recessions (Rutledge \& Coe, 2012). Thus, many older workers suffer through reduced retirement security and claim Social Security earlier than they would like to. Early retirement essentially reduces monthly monthly Social Security benefits by stretching them over a longer time frame. Thus, recessions increase the poverty among retirees, a group who face higher poverty races, especially women (Burn, Button, Figinski \& McLaughlin, forthcoming).

\section{How Might the Effects of the COVID-19 Pandemic and Recession be Different?}

The COVID-19 pandemic is an unprecedented challenge that disproportionately affects older people for numerous reasons. The most evident and horrifying impact is higher mortality and morbidity rates for older people. For those that get COVID-19, mortality rates are $8.6 \%$ for those in their 70 s, $4 \%$ for 60 s, $1.25 \%$ for 50 s, and $0.3 \%$ for those in their 40s (Begley, 2020). As of June 17, 2020, 92.6\% of COVID-19 deaths in the United States were those ages 55 and older (National Center for Health Statistics, 2020), despite this group being only $29.1 \%$ of the population (U.S. Census Bureau, 2020). Increased mortality among older people can also make older women more likely to become widowed. This increases poverty among older women, since widowed women face high poverty rates (Burn et al., forthcoming). 
For those that survive COVID-19, there are lingering negative impacts. Early evidence suggests that there are long-term impacts on health, such as blood clotting, strokes, embolisms, heart or lung damage, and neurological symptoms (Du, 2020). These conditions will reduce labor supply and will further increase applications to Social Security Disability Insurance, especially for older people, further straining the Social Security Trust Funds.

The effects on retirement savings thus far seem large. Equity holdings took a large hit. For example, Fidelity Advisors estimates that 401(k) plans balances fell about 19\% in the first quarter of 2020 and that individual retirement plan balances fell by 14\%. (Brandus, 2020). Low interest rates are reducing returns on short-term deposits and decreases in housing prices are reducing the housing equity that could be cashed in for retirement.

This decline in retirement security will motivate many older people to work longer to increase savings and delay Social Security claiming to increase monthly benefit amounts. A common way that older people work longer is through taking bridge jobs (Johnson, Kawachi, \& Lewis, 2009). Examples include managerial positions, transportation drivers, sales, and construction for men, and managerial, administrative/clerical, sales, and personal service for women (Cahill, Giandrea \& Quinn, 2011; Neumark, Burn \& Button, 2019).

However, workers in bridge jobs face an increased exposure risk to SARS-CoV-2. Using data from Montenovo et al. (2010), it appears that bridge jobs, especially for women, have higher rates of face-to-face contact and are less likely to allow for remote work, making these jobs riskier. Early evidence suggests that retirement increased significantly in the first months of the pandemic (Coibion, Gorodnichenko \& Weber, 2020), suggesting that older workers are retiring early instead of taking the risk. 
Even if older people brave the elevated risks to apply for jobs, they may face even more age discrimination in addition to the high levels of age discrimination that already occur, especially during recessions (Neumark \& Button, 2014). Employers may, for example, assume that older people are riskier to hire because their age group is statistically more susceptible to COVID-19. These barriers to working longer will increase early retirement, Social Security claiming, and increase poverty among retirees. For all these reasons, we anticipate that COVID-19 and the resulting recession will negatively impact older people more than prior recessions, which we now explore with some available data.

\section{Data}

We use data from the Current Population Survey (CPS), via IPUMS-CPS (Flood, King, Rodgers, Ruggles, \& Warren, 2020), to provide an early look (up to April 2020) at impacts on the employment outcomes of older workers. However, classifying the employment status of individuals has been error prone during the COVID-19 pandemic. Therefore, we calculate two versions of the employment rate and three versions of the unemployment rate.

The employment rate, as typically calculated, is the number of employed individuals, including those deemed "has job, not at work last week," divided by the population. However, the U.S. Bureau of Labor Statistics noted that survey enumerators often misclassified individuals as “has job, not at work last week” instead of “unemployed” (U.S. Bureau of Labor Statistics, 2020d). For this reason, we calculate a modified employment rate that excludes the "not at work" group, counting only those at work.

For the unemployment rate, we start by calculating the official unemployment rate (U-3) and the broader "U-6" unemployment rate, which counts marginally attached workers and those underemployed "for economic reasons" as unemployed. ${ }^{\mathrm{i}}$ However, even this broad U-6 rate could 
underestimate unemployment during the COVID-19 pandemic. We construct a "U-6+" rate, which broadens the U-6 rate by adding those who are underemployed for one of three reasons that could relate to COVID-19: own illness, injury, or medical problem; slack work, or business conditions; or on layoff (temporary or indefinite) (U.S. Bureau of Labor Statistics, 2020d).

\section{Results: Employment and Labor Force Participation Rates}

[Table 1 about here]

[Figure 1 about here]

Figure 1 presents employment rates by age group (ages 25-44, 55-64, 65+) and sex from January 1976 to April 2020. Table 1 summarizes the changes in all the employment and unemployment variables from the average in 2019 to April 2020. Figure 1 shows a substantial decrease in employment at the early onset of the COVID-19 pandemic, a clear outlier compared to the last five recessions (shaded in grey). Figure 1 and Table 1, panel A, show that this decrease was the most substantial in percentage point terms for ages 25-44: an 11.31 (10.56) percentage point decrease for men (women) in April 2020 compared to the average in 2019. The percentage point decrease is smaller for ages 55-64: 7.15 (7.54) for men (women), and ages 65+: 4.16 (3.07) for men (women).

While the smaller percentage point decrease in employment for older workers could be interpreted as COVID-19 having a more significant adverse effect on younger workers, percentage point changes in employment rates would be expected to be proportion to the rates themselves. Another way to estimate the change in employment rates is to calculate a percent change.

Workers 65+, namely women 65+, had the largest percent change. For women ages 65+ their average employment rate was $16.36 \%$ in 2019, and this decreased by 3.07 percentage points to $13.29 \%$ in April 2020. This is an $18.75 \%$ decrease in the employment rate, the largest decrease 
for all age and sex groups (for men $65+$ it was a $16.92 \%$ decrease). One way to conceptualize this is that out of 100 women (men) of ages 65 and older who were employed, about 19 (17) became non-employed. The percent decrease in the employment rate was smaller for the younger age groups: a $12.98 \%$ (14.27\%) decrease for men (women) of ages $25-44$, and $10.21 \%$ (12.92\%) decrease for men (women) of ages 55-64.

The way to interpret this discrepancy between larger percentage point decreases for younger workers and men, but larger percent decreases for older workers and women, is that the economic shock of COVID-19 hit employed individuals of ages 65+ and women more harshly, but while a smaller economic shock hit younger workers and men, there were more of them that were impacted due to higher existing employment rates.

Our alternative measure of employment (Table 1, panel B) that helps correct for possible misclassification errors shows larger percentage point and percent decreases in the employment rate, but otherwise, the patterns mirror those for the standard measure of employment.

[Figure 2 about here]

Figure 2 and Table 1, panel C, present labor force participation rates. There is no apparent decrease in the participation rate in previous recessions for any group, but there is an apparent decrease since January 2020 for those ages 25-44 and 65+ groups. Like with the employment rate, those ages 65+ experienced the largest percent decrease (5.59\%). However, the participation rate decreases for women are generally somewhat smaller. Unfortunately, the Current Population Survey data does not allow us to determine effects on the timing of retirement; however, early evidence from Coibion, Gorodnichenko \& Weber (2020)'s analysis of the Nielsen Homescan panel suggests that retirement has increased significantly.

\section{Results: Unemployment Rates}


[Figure 3 about here]

Figure 3 and Table 1, panel D, present the official (U-3) unemployment rates. The increase in the unemployment rate in April 2020 was dramatic and rapid, with unemployment rates increasing by a staggering 13.81 (11.36) percentage points for women (men) ages 65+, compared to the average rates in 2019, resulting in an unemployment rate of $16.85 \%$ (14.26\%) for women (men) ages 65+. Unemployment rates also increased significantly, but by less, for the younger age groups. For women (men) ages 25-44, the unemployment rate increased 10.39 (9.10) percentage points in April 2020, compared to in 2019. For women (men) ages 55-64, the unemployment rate increased 11.24 (8.42) percentage points. All these changes represent massive percent changes in unemployment rates, with unemployment rates being 282 to 454\% larger than they were in 2019. Older people and women faced both higher percentage point and percent increases in unemployment rates.

This rapid and severe increase in the unemployment rate is much more dramatic than the increases in previous recessions. In Figure 3, the increase in the unemployment rate in the early onset of COVID-19 is two to three times larger than in the peak of the Great Recession of 20072009. We also see that the COVID-19 recession impacted workers 65+ more than younger workers, while this is the opposite in previous recessions. This is clear early evidence that the COVID-19 pandemic and recession is hitting older workers harder.

[Figure 4 about here]

However, this picture is even worse for all workers, older workers especially, when we broaden how we calculate the unemployment rate to better capture the complicated employment picture during the pandemic. Figure 4 presents the broader U-6 unemployment rates by age group and sex, and Table 1, panel E, summarizes the percentage point and percent decreases in the U-6 
rate. U-6 rates are much higher than U-3 rates, with the U-6 rate in 2019 being between 2.5 and 4.2 times higher than the U-3 rate. The gap between the U-6 and U-3 rates is largest for workers 65+, especially women. Women (men) ages 65+ had a U-3 rate of 3.04\% (2.90\%) in 2019 but a U-6 rate of $12.50 \%$ (10.60\%). Women also face a larger gap between U-3 and U-6 rates. This suggests that older people and women are more likely to be marginally attached to the labor force and are also more likely to be underemployed.

Using the U-6 rate shows an even higher unemployment rate in April 2020: between 20.24 and $29.18 \%$ in April 2020. The percentage point increase in the U-6 rate is again the largest for ages 65+, especially women, but the difference in the percentage point increase by age group and sex is less pronounced using the U-6 rate.

However, even this broad U-6 rate could potentially underestimate unemployment due to the classification issues summarized above. We, therefore, constructed a "U-6+" rate, which adds those who are underemployed for COVID-19-specific reasons. Table 1, panel F, presents the percentage point and percent increases in our U-6+ rate. As expected, the U-6+ rate is slightly higher than the U-6 rate in 2019: between 0.91 and 1.39 percentage points higher. This broadest unemployment rate measure leads to unemployment rates of between 21.01 to $29.68 \%$ in April 2020. While the U-6 rate showed that the percentage point increase was slightly larger for those ages 65+, with our U-6+ rate, we do not find that those ages 65+ had a larger increase. However, we again find that the increase was more substantial for women, which is consistent for all measures of the unemployment rate.

\section{Conclusion}

Older workers are often hit hard by recessions, and often harder than younger workers. Recessions cause reductions in employment and earnings, increased early Social Security 
claiming, reduced retirement savings, and increased poverty at old ages. The COVID-19 pandemic and resulting recession hit older people, especially older women, even harder than past recessions. This is due both to the COVID-19 recession having a larger magnitude, but also because the pandemic creates additional risks for older workers that cut their (work) lives short.

In this report, we can only discuss early impacts, but the COVID-19 pandemic is ongoing. We plan to update our analysis as new data becomes available. We also plan to extend our analysis to make it more detailed, such as by studying intersectionality with race and ethnicity, as COVID19 is widening existing disparities faced by people of color.

There is significant room for future research, which can explore data that was not available to us. Data from the Health and Retirement Study is the most useful for studying older workers, although it is released with a long lag. For example, future work could use this data to analyze bridge jobs (see, e.g., Cahill, Giandrea \& Quinn, 2011) or effects on retirement and labor supply (see, e.g., Rutledge \& Coe, 2012).

\section{References}

1Point3Acres. (2020) Global COVID-19 Tracker \& Interactive Charts. https://coronavirus.1point3acres.com/en.

Begley, S. (2020, March 30). What explains Covid-19’s lethality for the elderly? STAT. https://www.statnews.com/2020/03/30/what-explains-coronavirus-lethality-for-elderly/.

Brandus, P. (2020, May 16). Thanks to COVID-19, Social Security’s day of reckoning may be even closer than we thought. MarketWatch. https://www.marketwatch.com/story/thanks-tocovid-19-social-securitys-day-of-reckoning-may-be-even-closer-than-we-thought-2020-04$\underline{15}$.

Burn, I., Button P., Figinski T., \& McLaughlin J. S. (Forthcoming). "Why Retirement, Social 
Security, and Age Discrimination Policies Need to Consider the Intersectional Experiences of Older Women." Forthcoming in Public Policy \& Aging Report.

Cahill, K. E., Giandrea, M. D., \& Quinn, J. F. (2011). How Does Occupational Status Impact Bridge Job Prevalence? BLS Working Paper 447. https://www.bls.gov/osmr/researchpapers/2011/pdf/ec110050.pdf.

Coibion, O., Gorodnichenko, Y., \& Weber, M. (2020). Labor Markets During the COVID-19 Crisis: A Preliminary View. NBER Working Paper 27017, Cambridge, MA. https://doi.org/10.3386/w27017

Coile, C. C., Levine, P. B., \& Mcknight, R. (2014). Recessions, Older Workers, and Longevity: How Long Are Recessions Good for Your Health? American Economic Journal: Economic Policy, 6(3), 92-119. https://doi.org/10.1257/pol.6.3.92.

Du, L. (2020, May 5). Virus Survivors Could Suffer Severe Health Effects for Years. Bloomberg. https://www.bloomberg.com/news/articles/2020-05-12/covid-19-s-healtheffects-can-last-long-after-virus-is-gone.

Flood, S., King, M., Rodgers, R., Ruggles, S., \& Warren, J. R. (2020). Integrated public use microdata series, Current Population Survey: Version 7.0 [Machine-readable database]. https://doi.org/10.18128/D030.V7.0

Johnson, R. W., \& Butrica, B. A. (2012). Age Disparities in Unemployment and Reemployment during the Great Recession and Recovery. Urban Institute Brief \#3, Washington, DC. https://www.urban.org/sites/default/files/publication/25431/412574-age-disparities-inunemployment-and-reemployment-during-the-great-recession-and-recovery.pdf.

Johnson, R. W., Kawachi, J., \& Lewis, E. K. (2009). Older workers on the move: Recareering in later life. In AARP Public Policy Institute Research Report. Washington, DC. 
http://www.urban.org/publications/1001272.html.

Montenovo, L., Rojas, F. L., Schmutte, I. M., Simon, K. I., Weinberg, B. A., \& Wing, C. (2020). Determinants of Disparities in COVID-19 Job Losses. NBER Working Paper 27132, Cambridge, MA. http://doi.org/10.3386/w27132.

Munnell, A. H., \& Rutledge, M. S. (2013). The Effects of the Great Recession on the Retirement Security of Older Workers. Annals of the American Academy of Political and Social Science, 650(1), 124-142. https://doi.org/10.1177/0002716213499535.

Munnell, A. H., Webb, A., \& Golub-Sass, F. (2012). The National Retirement Risk Index: An update. CCR Issue in Brief 12-20, Chestnut Hill, MA. https://crr.bc.edu/wpcontent/uploads/2019/12/IB_12-20.pdf.

National Center for Health Statistics. (2020). Provisional COVID-19 Death Counts by Sex, Age, and State. https://data.cdc.gov/widgets/9bhg-hcku.

Neumark, D., Burn, I., \& Button, P. (2019). Is It Harder for Older Workers to Find Jobs? New and Improved Evidence from a Field Experiment. Journal of Political Economy, 127(2), 922-970. https://doi.org/10.1086/701029.

Neumark, D., \& Button, P. (2014). Did Age Discrimination Protections Help Older Workers Weather the Great Recession? Journal of Policy Analysis and Management, 33(4), 566601. https://doi.org/10.1002/pam.21762.

Rutledge, M. S., \& Coe, N. B. (2012). Great Recession-Induced Early Claimers: Who are They? How Much Do They Lose? CRR Working Paper 2012-12, Chestnut Hill, MA. https://crr.bc.edu/wp-content/uploads/2012/04/wp 2012-12-508.pdf.

U.S. Bureau of Labor Statistics. (2020a). The Employment Situation - March 2020. https://www.bls.gov/news.release/archives/empsit_04032020.pdf. 
U.S. Bureau of Labor Statistics. (2020b). The Employment Situation - April 2020. https://www.bls.gov/news.release/archives/empsit 05082020.pdf.

U.S. Bureau of Labor Statistics. (2020c). Labor Force Statistics from the Current Population Survey: LNU04000000.

U.S. Bureau of Labor Statistics. (2020d). BLS COVID-19 Questions and Answers. Retrieved June 18, 2020 from https://www.bls.gov/covid19/home.htm.

U.S. Census Bureau. (2020). Table 1. Population by Age and Sex: 2019. 
Table 1. Changes in Employment Statistics by Age Group and Sex, April 2020

\begin{tabular}{|c|c|c|c|c|c|c|c|c|c|}
\hline & \multicolumn{3}{|c|}{ Ages 25-44 } & \multicolumn{3}{|c|}{ Ages 55-64 } & \multicolumn{3}{|c|}{ Ages 65+ } \\
\hline & Men & Women & Combined & Men & Women & Combined & Men & Women & Combined \\
\hline \multicolumn{10}{|l|}{ A: Employment rate (\%): } \\
\hline Average rate in 2019 & 87.07 & 73.97 & 80.46 & 70.04 & 58.38 & 64.00 & 24.59 & 16.36 & 20.05 \\
\hline Rate in April 2020 & 75.76 & 63.41 & 69.54 & 62.89 & 50.84 & 56.64 & 20.43 & 13.29 & 16.50 \\
\hline Percentage point change & -11.31 & -10.56 & -10.46 & -7.15 & -7.54 & -7.36 & -4.16 & -3.07 & -3.55 \\
\hline Percent change (\%) & -12.98 & -14.27 & -13.58 & -10.21 & -12.92 & -11.49 & -16.92 & -18.75 & -17.72 \\
\hline \multicolumn{10}{|c|}{ B: Employment rate, excluding "not at work last week" (\%): } \\
\hline Average rate in 2019 & 85.09 & 70.99 & 77.98 & 67.60 & 55.85 & 61.51 & 23.36 & 15.44 & 18.99 \\
\hline Rate in April 2020 & 70.60 & 57.67 & 64.08 & 57.90 & 45.71 & 51.58 & 17.64 & 11.33 & 14.17 \\
\hline Percentage point change & -14.49 & -13.32 & -13.90 & -9.70 & -10.14 & -9.93 & -5.72 & -4.11 & -4.82 \\
\hline Percent change (\%) & -17.02 & -18.76 & -17.82 & -14.34 & -18.17 & -16.13 & -24.48 & -26.59 & -25.40 \\
\hline \multicolumn{10}{|c|}{ C: Labor force participation rate (\%): } \\
\hline Average rate in 2019 & 89.96 & 76.56 & 83.20 & 71.84 & 59.97 & 65.68 & 25.32 & 16.87 & 20.66 \\
\hline Rate in April 2020 & 86.41 & 73.54 & 79.92 & 70.60 & 59.04 & 64.61 & 23.82 & 15.99 & 19.51 \\
\hline Percentage point change & -3.55 & -3.02 & -3.28 & -1.24 & -0.93 & -1.07 & -1.50 & -0.88 & -1.15 \\
\hline Percent change (\%) & -3.95 & -3.94 & -3.94 & -1.72 & -1.55 & -1.64 & -5.91 & -5.26 & -5.59 \\
\hline \multicolumn{10}{|c|}{ D: Official (U-3) unemployment rate (\%): } \\
\hline Average rate in 2019 & 3.22 & 3.38 & 3.29 & 2.50 & 2.65 & 2.57 & 2.90 & 3.04 & 2.96 \\
\hline Rate in April 2020 & 12.32 & 13.77 & 12.99 & 10.92 & 13.89 & 12.33 & 14.26 & 16.85 & 15.43 \\
\hline Percentage point change & 9.10 & 10.39 & 9.70 & 8.42 & 11.24 & 9.76 & 11.36 & 13.81 & 12.47 \\
\hline Percent change (\%) & 282.97 & 307.29 & 294.49 & 336.76 & 424.52 & 379.68 & 391.54 & 453.78 & 420.83 \\
\hline \multicolumn{10}{|c|}{ E: U-6 Unemployment rate (\%): } \\
\hline Average rate in 2019 & 7.26 & 8.40 & 7.79 & 6.49 & 7.46 & 6.95 & 10.60 & 12.50 & 11.46 \\
\hline Rate in April 2020 & 22.67 & 24.95 & 23.73 & 20.24 & 23.98 & 22.02 & 26.23 & 29.18 & 27.57 \\
\hline Percentage point change & 15.41 & 16.55 & 15.94 & 13.75 & 16.52 & 15.07 & 15.63 & 16.68 & 16.11 \\
\hline Percent change (\%) & 212.27 & 196.88 & 204.51 & 211.86 & 221.41 & 216.77 & 147.36 & 133.40 & 140.59 \\
\hline \multicolumn{10}{|c|}{ F: “U-6+" unemployment rate (\%): } \\
\hline Average rate in 2019 & 8.17 & 9.73 & 8.90 & 7.50 & 8.85 & 8.14 & 11.57 & 13.76 & 12.56 \\
\hline Rate in April 2020 & 23.32 & 25.49 & 24.33 & 21.01 & 24.74 & 22.78 & 26.43 & 29.68 & 27.91 \\
\hline Percentage point change & 15.15 & 15.76 & 15.43 & 13.51 & 15.89 & 14.64 & 14.86 & 15.92 & 15.35 \\
\hline Percent change (\%) & 185.28 & 161.97 & 173.39 & 180.07 & 179.62 & 179.87 & 128.40 & 115.75 & 122.17 \\
\hline
\end{tabular}

Notes: Author's calculations using data from the Current Population Survey (monthly) from 1976 to April 2020, via IPUMS-CPS (Flood et al., 2020). We use the average rate in 2019 rather than the rate in April 2019 to reduce sampling variation. All estimates are not seasonally adjusted. All estimates are weighted using population weights. 


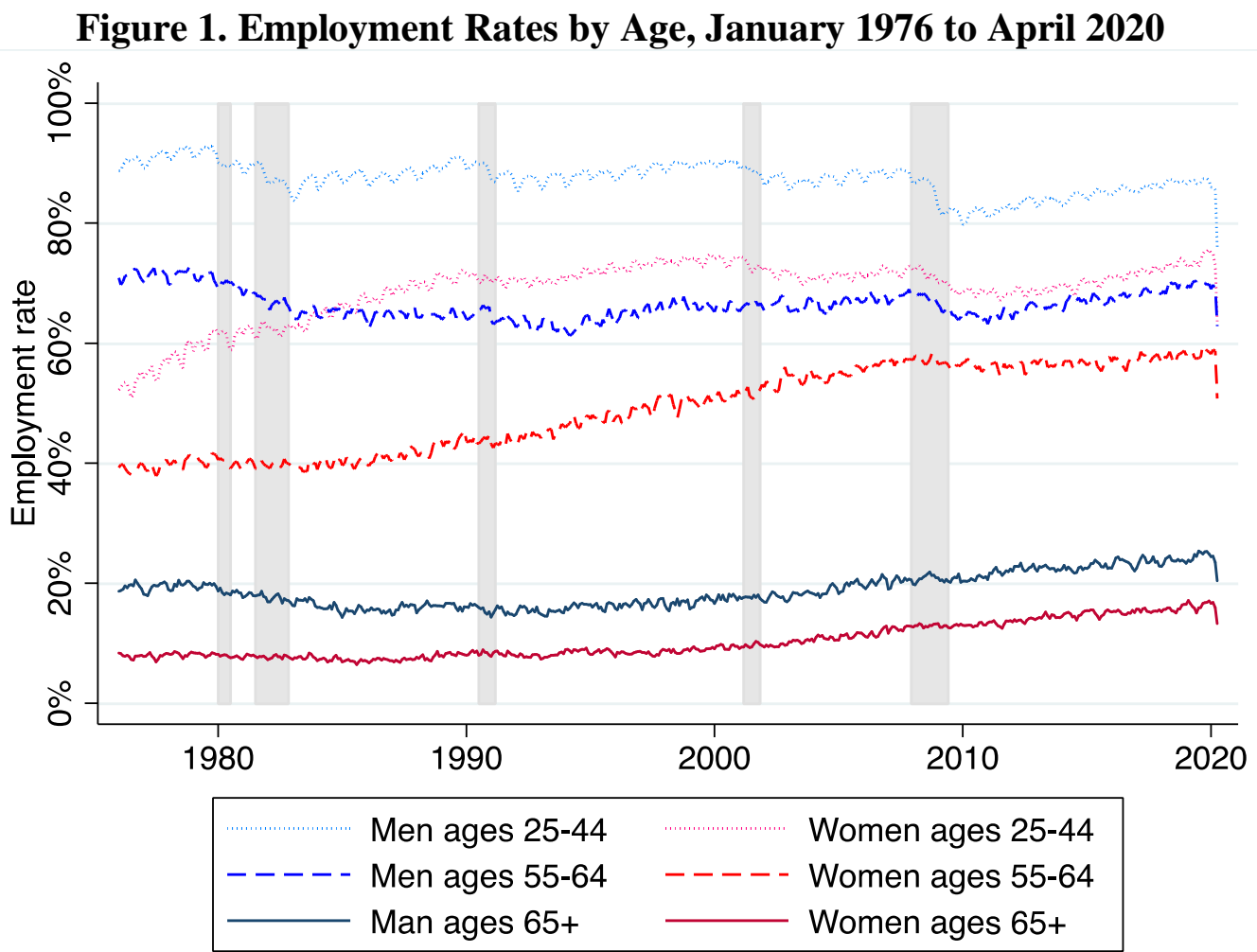

Notes: Author's calculations using data from the Current Population Survey (monthly) from 1976 to April 2020, via IPUMS-CPS (Flood et al., 2020). These estimates are not seasonally adjusted. Shaded areas represented official recession dates from the NBER (https://www.nber.org/cycles/cyclesmain.html). See also the notes to Table 1. 
Figure 2. Labor Force Participation Rates by Age, January 1976 to April 2020

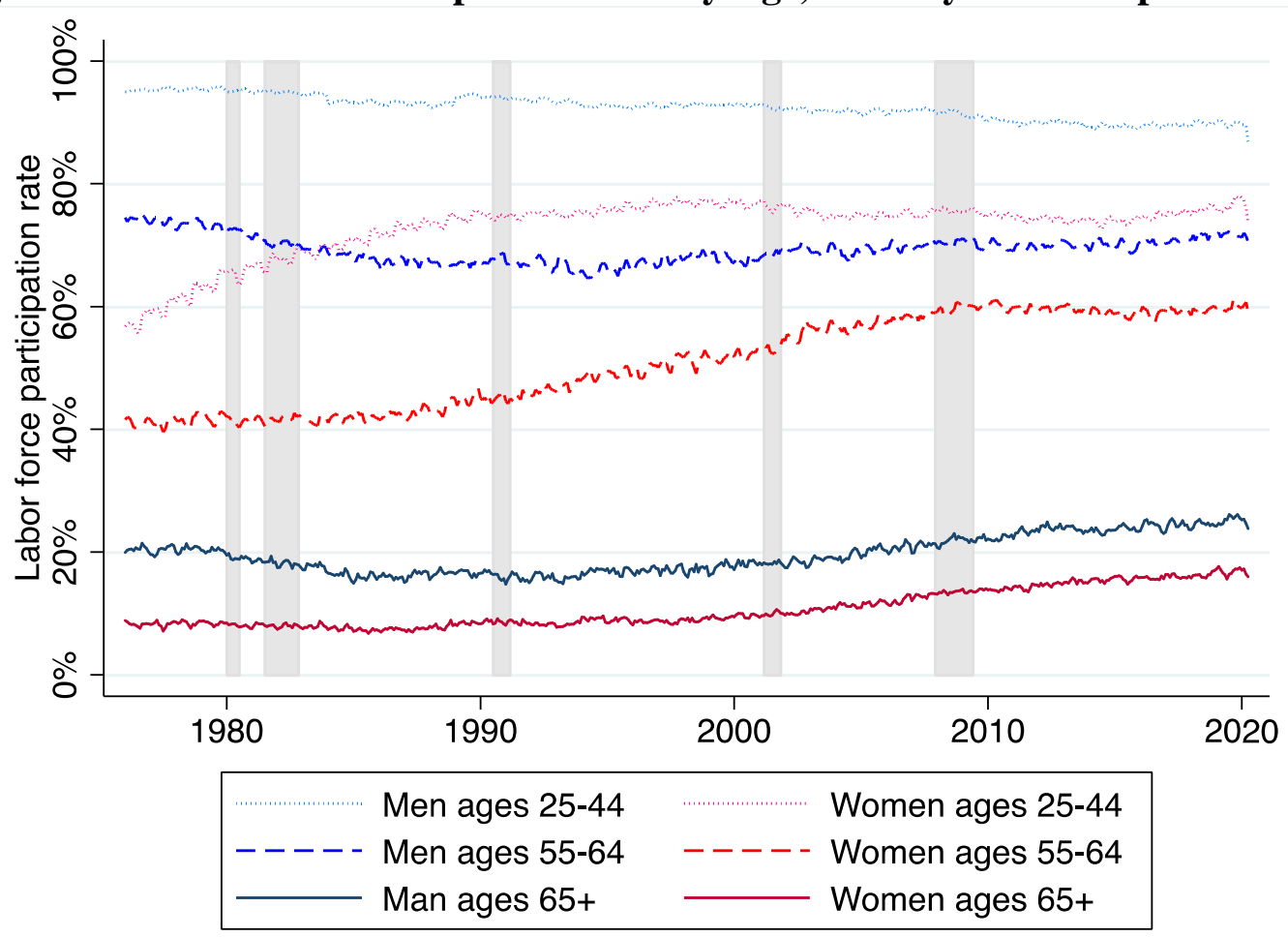

Notes: See the notes to Table 1 and Figure 1. These estimates are not seasonally adjusted. 
Figure 3. Official (U-3) Unemployment Rates by Age, January 1976 to April 2020

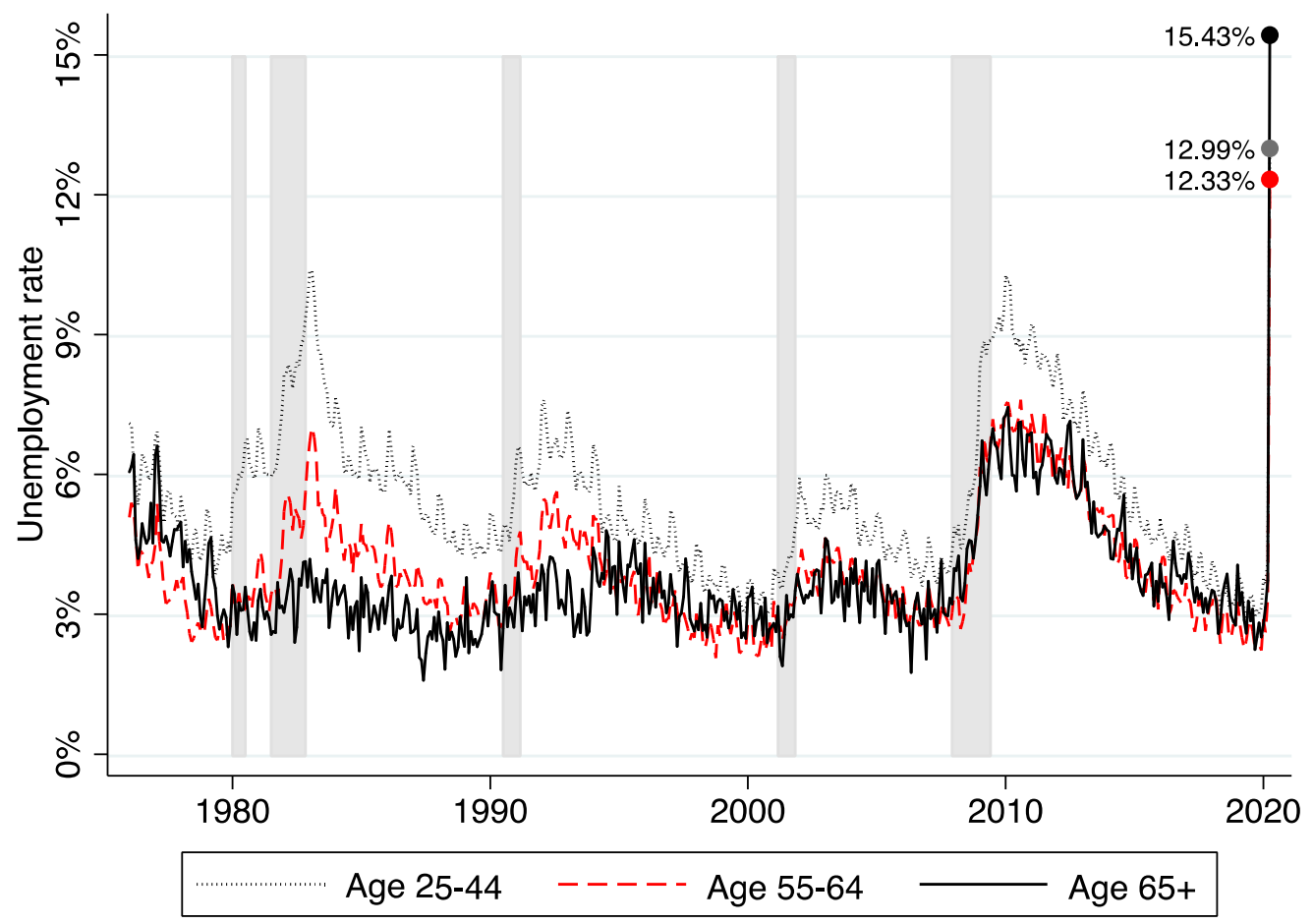

Notes: See the notes to Table 1 and Figure 1. These estimates are not seasonally adjusted. 
Figure 4. U-6 Unemployment Rates by Age, January 1994 to April 2020

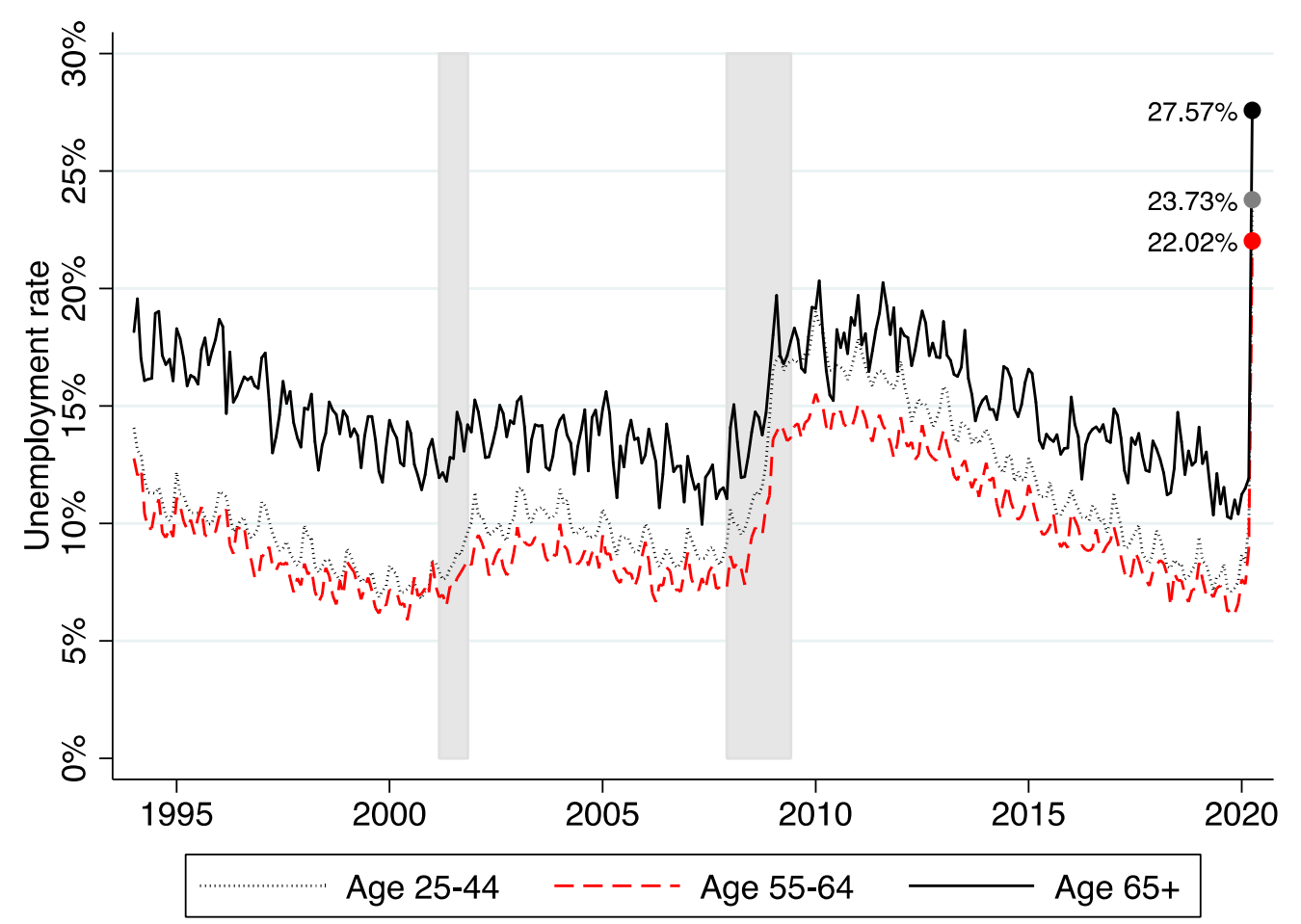

Notes: See the notes to Table 1 and Figure 1 . These estimates are not seasonally adjusted.

\footnotetext{
${ }^{\mathrm{i}}$ Marginally attached individuals are those who searched for work sometime within the last 12 months, but not within the last four weeks (searching in the last four weeks is a requirement to be deemed unemployed). Included within marginally attached workers are discouraged workers, who stopped searching because they were discouraged about job prospects. Those deemed underemployed "for economic reasons" are individuals who work part time, report that they would like to work full time, but cannot find a full-time job.
} 